\title{
THE LIMITATIONS OF THE ACTION OF ASSUMPSIT AS AFFECTING THE RIGHT OF ACTION OF THE BENEFICIARY.
}

"I take it that the ancient notion about the want of Consideration was for the sake of Evidence only."-LoRD MANsFIELD in Pillans \& Rose v. Van Mierop \& Hopkins, 3 Burrows at page 1669 ( 1765$)$.

"The true interest of the topic of Procedure is derived, from the manner in which the tribunals have contrived from time to time to effect changes in the substance of the law itself, under cover of merely modifying the methods by which it is enforced."-Holland: "Elements of Jurisprudence," chap. xv. page 267 ( 1888 ).

"But when the court was informed that the ancient form was such, then they changed their opinion and awarded the writ good, and resolved, that common course makes a law, although now, as it was there said, perhaps reason willeth the contrary; but there the Justices said, we cannot change the law now, for that would be inconvenient, and therewith agrees Long 5 E.4 I, where it is said, that the course of a court makes a law."Slade's Case, 4 Rep. (93), 44 Eliz.

Modern English law, in a familiar line of decisions since the year 1724 , has pronounced against the right of a third person, not a party to a contract, to maintain an action of assumpsit upon the contract, even though it was made for his benefit. ${ }^{1}$

Upon examination of these cases, the following questions are presented:

Is there any substantive right by which the beneficiary of a contract can enforce it apart from the action of assumpsit?

Is the denial of the beneficiary's right in the English cases of assumpsit due to a judicial denial of the existence of such a substantive right; or is the inability of the beneficiary to recover

${ }^{1}$ Crow v. Rogers, r Strange, 592 (1724); Price v. Easton, 4 Barn. and Ad. 433 (1833); Tweddle v. Atkinson, I B. and S. 393 (1861); Empress Engineering Co., 16 Chancery Div. 125, 129 (1880), Re Rotherham Alum and Chemical Co., 25 Ch. Div. at page II ( 1883 ); Cleaver v. Mutual Reserve Fund Life Association, I Q. B. 147 (1892). 
in the English decisions due in reality to certain technicalities of procedure or of substantive law incident to the action of assumpsit itself?

If, apart from assumpsic, there is such a substantial right of a beneficiary, what is its basis, its scope, and its limitations, and in what formal procedure is it enforceable?

"Whatever disadvantages the English law on the question may have, it has at least the merit of definiteness. A beneficiary has no legal rights." 2 That the English judicial conscience finds satisfaction in this conclusion may be seen from the exclamation of Crompton, J.: "It would be a monstrous proposition to say that a person was a party to the contract for the purpose of suing upon it for his own advantage, and not a party to it for the purpose of being sued." 3

That the English courts in preventing this monstrosity have not sacrificed any cherished English judicial principle appears from the repeated assurances of the English judges that the beneficiary cannot recover because he is "a stranger to the consideration," and because "he is not a party to the contract." "4

Unfortunately, however, for legal uniformity, the monstrosity of the proposition that a person may be entitled to sue on a contract without being himself liable to suit thereon has hardly shocked any judicial consciences outside of England. Continental Europe has in many codes recognized the right of action of the beneficiary. ${ }^{5}$ The Supreme Court of the United States has said that "The right of a party to maintain assumpsit on a promise not under seal made to another for his benefit, although much controverted, is now the prevailing rule in this country." 6

Some American states by code provisions have conferred.

\footnotetext{
" Contracts for the Benefit of a Third Person," by Samuel Williston, xv Harvard Law Review, 774 (1902).

'Tzueddle v. Atkinson, I Best and Smith, 398 (I86I).

- Price v. Easton, 4 Barn. and Ad. 433 (1833); Thomas v. Thomas, 2 Ad. and El. N. S. 851,859 (1842).

" "Contracts for the Benefit of a Third Person in the Civil Law," by Samuel Williston, xvi Harvard Law Review, 43 (1902).

'Hendrick v. Lindsaj', 93 U. S. I43 (1876).
} 
rights of action on the beneficiary in certain enumerated instances, notably in contracts of life insurance. ${ }^{\top}$ Other American States by their judicial interpretation of the common law have declared the right to exist under certain conditions and restrictions. $^{8}$

It is safe, therefore, to assume as an abstract proposition, and aside from the technicalities of procedure, that modern commercial sentiment outside of England is in favor of effectuating the intention of the contracting parties who have attempted to confer rights on a third party in respect of their contract.

Any system of contract law which undertakes to say that A cannot, under any circumstances, contract with $B$ so that $C$, who by the contract is to be beneficially affected by B's performance, cannot enforce his performance, when $A$ ceases to desire, and hence is unwilling to compel B's performance, and $C$ has therefore become the only person interested in it, occupies an antipodal position with respect to the jurisprudence of modern civilized commercial states.

Such is the position of English law at the present day. Such, consequently, is the position of the law in those American states which are content to follow English precedents. In other states the right of action is granted to the beneficiary, but in language that is unmistakedly apologetic, recognizing the English principle and limiting the American exceptions to certain circumstances supposed to be peculiar. Of this so-called American rule it has been truly said by Pollock that "there does not seem to be any general agreement as to its reason or its precise extent." 9

Altogether, the hope of any uniformity of decision in America is rapidly reaching the vanishing point. That various courts of common-law origin, professedly expounding and administering that law, should reach not only contrary conclusions on this problem, but conclusions involving fundamentally atagonistic con-

\footnotetext{
' "Contracts for the Benefit of a Third Person," by Samuel Williston, xv Harvard Law Review, page 778, (1902).

3 "Ib., pages 778, 779, 780, 781.

'Pollock on Contracts, 7 th ed, page 215 .
} 
ceptions of the doctrine of consideration, provokes the inquiry, whether the common law on the subject has ever been investigated, ascertained, and presented.

It has been repeatedly said that the beneficiary can have no right of action because of the doctrine of consideration, or, to put the statement more explicitly, that the doctrine of consideration requires the plaintiff to have furnished the consideration and also to be the promisee. As the beneficiary does not fulfil either of these requisites, therefore he cannot recover.

The only line of approach in investigating the common law on this subject lies in challenging and demanding proof for the propositions so often asserted that:

(I.) No one can recover on a contract except the person who furnishes the consideration.

(2.) No one can recover on a contract except the promisee.

We find both these propositions asserted in the English decisions in the action of assumpsit. That the foregoing two propositions are invariably discussed solely from the stand-point of the action of assumpsit is apparent from the following opinions of the leading text-writers. There is, however, no consensus of opinion among text-writers with respect to the truth of both propositions.

Judge Hare, in his work on Contracts, page 146, says "that the only person entitled to sue on a contract is he who furnishes the consideration." 10

Oi course, such a rule effectually bars any action by a third party brought to enforce a contract made for his benefit. The reluctance of this learned writer to admit that this test should be applied remorselessly to all actions of the beneficiary appears in

10 " It is a well-established rule of the common law that the right of action lay not with him to whom the promise was made and who would have been benefited if it had been kept, but with the party from whom the consideration moved on the faith of the promise (citing Pattison, J., in Thomas v. Thomas). . . . The rule may be traced in the reports from the origin of the action of assumpsit down to our own times, although it is not infrequently modified or superseded by principles which the common law has derived from equity (citing Bourne v. Mason, I Ventris, 6)." 
his concession on page 194, that "The question when a delivery to one man for the use of another will confer a right on the latter is, nevertheless, one of the most difficult and doubtful known to the law."

Professor Langdell contends that no person can enforce a contract except the promisee. ${ }^{11}$ Such a rule, if true, also defeats the right of action of the beneficiary where he is not the promisee. But obviously the two theories cannot both be correct. If the only requisite of a right to enforce a contract is to have furnished the consideration, then a person may enforce a contract even if he is not the promisee. In fact, we find Judge Hare asserts the following proposition-the exact contradictory of Professor Langdell's-as one of the arguments for the contention that the furnishing of the consideration is the sole test of the right of action: "If $A$ promised to pay $B £ I 000$ if $C$ would go to Rome, and $C$ took the journey, he and not $B$ is regarded as entitled to the reward, and to compel the payment of it by suit." 12 Leake interprets the doctrine of consideration to mean that although the consideration need not be furnished directly by the promisee, yet if furnished by a third party it must have been furnished at the promisee's request. ${ }^{13}$

Professor Williston admits that "The rule that consideration must move from the promisee is somewhat technical, and in a developed system of contract law there seems no good reason why $A$ should not be able for a consideration received from $B$ to make an effective promise to C." 1* Professor Williston, how-

${ }^{11}$ Langdell, Summary of the Law of Contract, sec. 62:

" A binding promise vests in the promisee, and in him alone, a right to compel performance of the promise, and it is by virtae of this right that an action is maintained upon the promise. In the case of a promise made to one person for the benefit of another, there is no doubt that the promisee can maintain an action, not only in his own name, but for his own benefit. If, therefore, the person for whose benefit the promise was made could also sue on it, the consequence would be that the promisor would be liable to two actions. In truth, a binding promise to $A$ to pay $\$ 100$ to $B$ confers no right upon $B$ in law or equity. It confers an authority upon the promisor to pay the money to $B$, but that authority may be revoked by A at any moment."

12 Hare on Contracts, page 147.

is Leake on Contracts, page 430.

" "Contracts for the Benefit of a Third Person," by Samuel Williston, xv Harvard Law Review, page 77 I (I902). 
ever, denies the right of action of the beneficiary on the other ground-" "The beneficiary is not a party to the contract, and, apart from some special principle governing this class of cases, cannot maintain an action." 15

The foregoing presentation of the attitude of well-known writers is sufficient to show that so far as the question is a legal and not an equitable question they all attempt to solve the problem of the beneficiary's right of action by the aid of the doctrine of consideration in assumpsit, i.e., as a question of procedure in assumpsit and not as one of substantive law. In fact, all the decisions cited on the right of action of the beneficiary are decisions in actions of assumpsit or in actions on the case; and, hence, these decisions turn on the English doctrine of consideration, and are controlled and limited by the judicial interpretations of that doctrine.

The citation of these decisions in case and assumpsit therefore proves nothing, because by the very nature of such actions hey rest on the doctrine of consideration, and no one who has not furnished the consideration, or, at least, no one who is not the promisee, has, according to the unanimous opinion of English judges, the right to maintain assumpsit.

The real question is, however, a much broader one. Is there any substantive right of action conferred by the common law on the beneficiary of a contract independent of assumpsit and therefore independent of the doctrine of consideration, i.e., independent of his having furnished the consideration and of his being the promisee?

The doctrine of consideration was, of course, unheard of in England until the reigns of Henry VIII and Elizabeth, when it came into vogue in the extension of the action on the case to promises previously unenforceable. "The name 'consideration' appears only about the beginning of the sixteenth century, and we do not know by what steps it became a settled term of art." 16 Outside of the action on the case and its derivative assumpsit, it

is "Contracts for the Benefit of a Third Person," by Samuel Williston, xv Harvard Law Review, page 773 (I902).

${ }^{18}$ Pollock on Contracts, 7th ed., page 170. 
the doctrine of consideration was never recognized and had never bcen heard of or applied.

But the right of action of the beneficiary was an established right long before the doctrine of consideration existed. The right of action of the beneficiary was previously recognized and firmly established in the ancient actions of debt and of account years before the rise of the action of case on "promises." The doctrine that neither case nor assumpsit would lie except for a consideration, and finally the definition of consideration as consisting in a detriment suffered by the plaintiff who must be the promisee had obviously no place in the action of debt where "there was no theory of consideration, and therefore, of course, no limit to either the action or the contract based upon the nature of the consideration received." 17

The development of consideration in assumpsit in relation to the rights of third parties will be discussed later. We shall first deal with debt and account, where consideration was of course unknown, and examine the cases giving the beneficiary a right to sue in those actions.

\section{THE ACTIONS OF DEBT. AND OF ACCOUNT, AND THE RIGHT OF ACTION OF THE BENEFICIARY.}

In 1368 (4I Ed. III) in an action of account; the facts were that the plaintiff had bailed to the defendant ten pounds, upon condition that if the defendant made the plaintiff an assurance of certain lands, that he should have the ten pounds, and that if he did not make assurance at a certain day, that he slould rebail the money to the plaintiff. The plaintiff claimed that the defendant did not make the assurance, and brought a writ of account for the money. The question was, whether plaintiff's remedy was by a writ of account or a writ of debt. Cavendish (then Sergeant): "If I bail certain moneys to you to bail to John, he shall have writ of account because the property is in him immediately when you receive them by my hand, and he cannot have account by writ of debt." This assertion of Cavendish

${ }^{27}$ Holmes on the Common Law, page 271 . 
was unchallenged, and he speaks of it as familiar law. The dispute in the principal case turned, of course, on the question, in whom was the property to the money while it was in the hands of the bailee? It was held that the action of account would lie by the bailor in this case on the theory, of course, that the title to the property had always remained in him. The contention of Cac'ctdish was, "at the time of the bailment the property was in him who received it, and upon condition broken the action accrued to him who bailed, to demand the money in action of debt." Thorpe, Chief Justice of the Common Pleas, thought the plaintiff could have either writ and that; therefore, account would lie. ${ }^{18}$

In 1405 ( 6 Hen. IV), in the Common Pleas, debt was brought to recover $40 s$. delivered to the defendant by the lessee of a manor to pay to the plaintiff. It was held that the proper remedy" was not debt because "there is 10 contract bctriccn y'ous." 19 Account would have been proper had there not been a franktenement. Hence a writ of annuity was the only remedy.

In 36 Hen. VI ( $145^{8}$ ), Wangford's language shows unmistakably not only that the beneficiary lad a right of action, but that the old distinction between debt and account to enforce his right was becoming obliterated. "Sir, I grant willingly that this is a good plea; and the reason is because when a man pays to another certain money by my commandment to my 'oeps,' if he who receives this money is unwilling to pay me, I shall have a good writ of debt or. account against him, and in that way $I$ will have my money." 20

In 1537 ( 28 Henry VIII) ${ }^{21}$ Montague said: "For inasmuch as a man has received money and has not employed and bestowed it according to the trust and condition, he is a.guardian of the same money to my use, as my debtor if I will, for it is the greater prejudice to me, if I choose my action of debt, thereby I shall recover only the bare sum that

\footnotetext{
22 Y. B., 4I Ed. III, folio Io, placitum 5.

${ }^{20}$ Y. B., 6 Hen. IV, folio 7 , placitum 33 .

$=$ Y. B., 36 Hen. VI, 8-5 at bottom of 9

2 Dyer, 125.
} 
an action of account I shall recover the increase and the profit of the same lent. And inasmuch as a man has two actions given by the law, he can choose whichever he wishes."

In 1587 , in the Queen's Bench, in 30 Eliz., in an action of account Andrews et ux. and one Cocket declared against Robsert that he, Robsert, on 20 Aug., Io Eliz., was the receiver of the money of the said Cocket and Ann, the wife of the plaintiff Andrews.

"It was found by special verdict that the Io Aug., Io Eliz., one $M$ gave the said $£$ Ioo for the relief of the said Cocket and Ann and delivered the same to the said Wase, then his servant, to the intent he should deliver it to the said Robsert for the relief of the said Ann and Cocket; and that he, the said Wase, did deliver it to the said Robsert for the relief of the said Ann and Cocket, according to the said intent."

. . . "It was adjudged he shall be said to be their receiver, and that he shall account with the said then plaintiffs for the said fIoo."

The writ of account was allowed. ${ }^{22}$

In 1612 "It was said by Cook, C. J.," in Common Pleas "and agreed by the whole court, and $4 \mathrm{I}$ and $43 \mathrm{E}$. 3 , etc., that if a man deliver money unto J. S. to my use, that I may have an action of debt or account against him for the same at my election." 23

In 1624 , in $23 \mathrm{Jac}$, an action of debt was brought by one Harris against one Peter De Bervoir "supposing that one Squire delivered to the defendant $f I 00$ to pay to the plaintiff, and that he had not paid it to the plaintiff: wherefore he brought this action. After verdict upon non debet, it was moved, in arrest of judgment, that debt lies not; for there never was any contract betwixt the plaintiff and defendant, nor any delivery of the money by the plaintiff to the defendant, and therefore no action of debt lies; yet peradventure he might have account upon this receipt; but no other action." The precedent 36 Hen. VI, pl. Io, and 39

${ }^{22}$ Cro. Eliz. 82, Robsert v. Andrews (1857).

${ }^{2}$ Clark's Case, Godbolt, 210 (1612). 
Hen. VI, pl. 44, were cited by the plaintiff to the effect "that cesty que use the delivery is made may have debt or account.

"And of that opinion were Doderidge and Lea: wherefore rule was given that judgment should be entered for the plaintiff, unless other cause, etc." 24

In 1638 , in 13 Charles $I$, we have this case: "If $A$, who is the uncle of $B$, an infant, gives $f_{I 2}$ to $J$. S. to educate $B$, the infant, and in consideration thereof $J$. S. promises to educate $B$ and also at his majority to pay to him, to infant $B$, the said $\mathfrak{E}_{\mathrm{I}} 2$, $B$ when he comes of age poet aver un action sur le case vers J. S. pur le $£ 12$ sil ne ceo pay solonque son promise." 25

In I649, in 24 Charles I, occurred this case: "If A and B are bound in an obligation to pay to $C £ 20$ when he comes to the age of $2 \mathrm{I}$, and then $\mathrm{A}$ assigns them to $\mathrm{D}$ and in consideration of this assignment $D$ promises to $C$ to pay him the $£ 20$ when he comes to the age of $2 \mathrm{I}$ years, quant il vient al age de $2 \mathrm{I}$ ans avera action sur le case sur cest promise vers $D$. Coment que nul consideration vient de $\mathrm{C}$. Car si home deliver deners al J. S. a paier ouster al $B$ en satisfaction de un debt due a luy, ceo raise un debt al $B$ et ne poet estre revoke et issint icy." 26

In $165 \mathrm{I}$, in 26 Charles I, we have this case: If $A$ gives goods to $B$ of the value of $£ 80$ out of which he shall pay to $C$ $\mathfrak{f 2}_{20}$, if $B$ does not pay the $\mathfrak{f 2}_{2}$ to $C, C$ poet aver un action sur le case vers $B$, et declare que il fuit indebted a luy en $\mathfrak{f 2 0}$, pur biens del value de $£ 80$, done a luy per $A$ hors de que il paiera $£ 20$ al C. Car quant les biens de value de $£ 80$ sont done al $B$ per agreement enter luy et $A$ que il paiera $£ 20$ al $C$ ceo deveigne un debt al C. Come jeo deliver $\mathfrak{f}_{2} \mathrm{O}$ al $\mathrm{B}$ a paier ouster al $\mathrm{C}$, $C$ poet aver un action de debt, ou accompt ou action sur case pur ces vers B. ${ }^{27}$

In I673 ( 13 Car. II), in King's Bench, an action of case was brought by Delabar v. Gold. "Gold owed Wood ten pounds

\footnotetext{
"Harris v. De Bervoir, Croke, James, 687.

${ }^{25}$ Oldham v. Bateman, I Rolle, $3 \mathrm{I}-8$ ( 1638 ).

"Disborne v. Denabie, I Rolle, 3 I (I649).

"Starkey v. Mylne, I Rolle, 32-13 (I65I).
} 
for which plaintiff sued Wood, and attached the money in Gold's hand, upon which this promise was made, . . . in consideration that plaintiff will forbear his attachment." The defendant, Gold, agreed "to pay such money as was in Gold's hand to the plaintiff." Wyndham and Twisden, JJ., were of opinion that the action of debt would lie. Wyndham, J.: "If the promise were in consideration $A$ hath sold goods to $B$ he promiseth to $C$ ten pounds, $C$ hath no remedy, because he is but an attorney of $A$ to receive for his use; and $A$ only can have an action upon the case against $B$ for not paying the money to $C$. But if $A$ sells to $C$, and $B$ promiseth in consideration thereof to pay to $C$ ten pounds, which $A$ owed to $C$, in this case $C$ shall have an action, because it appeareth that the interest was his . . . and here the defendant has done an act on the behalf of the plaintiff and there is a debt due for that which he hath done for the plaintiff, and so he may be entitled to the actions." Twisden, J.: "In Donabey's case, it was said, that it matters not from whom the consideration moveth, but who hath the benefit thereby." 28

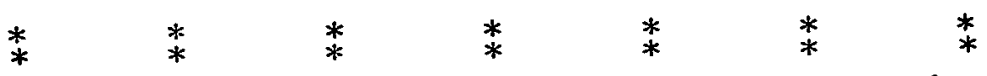

The substantive right of the beneficiary to bring an action of debt or an action of account at common law must now be summarized from the preceding and other cases.

First, however, the phraseology of mediaval law must be considered; for the mediæval lawyer had a legal.vocabulary of his own, and unless we understand his terms we cannot understand the substantive rights which his law recognized. "The word contract was used in the time of the Year Books in a much narrower sense than that of to-day. It was applied only to those transactions where the duty arose from the receipt of a quid pro $q u o, e . g$., a sale or loan. In other words, contract meant that which we now mean by 'real contract.' What we now call the formal or specialty contract was anciently described as a grant, and obligation a covenant, but not as a contract." ${ }^{29}$

${ }^{25}$ Keble, $44,63,122$.

"20 "Parol Contracts Prior to Assumpsit," by James Barr Ames, viii Harvard Law Review, page 253, note 3 . 
The rule was that a third person could recover in debt and in account against a defendant, notwithstanding there was no "contract" between them. Taking the word "contract" in its true mediæval sense, as used in the Year Books and paraphrasing it by a familiar modern expression, we are able to assert that the plaintiff in account and debt was not required to have furnished the consideration.

The rule is equally plain that the plaintiff in account and debt was not required to be privy to the "contract" or, as we should now say, "the promisee."

Ownership by the third party of the money or thing bailed was neither essential to, nor was it at all present in, the basis of the right to bring account or debt.

It is perfectly true, as has been said by Ames, that in debt "the defendant was conceived of as having in his possession something belonging to the plaintiff. which he might not rightfully keep, but ought to surrender." 30 But Ames here is describing a juridical conception which does not mean that in every case the thing sought must be proved to have belonged to the plaintiff. This conception was in reality the explanation of the judicial reasoning by which debt for property loaned by the plaintiff ${ }^{31}$ expanded in a later age into debt for money due on a "real contract."

"In its earliest stage the action is thought of as an action whereby a man 'recovers' what belongs to him. It has its root in the money loan; for a very long time it is chiefly used for the recovery of money that has been lent. The case of the unpaid vendor is not-this is soon seen-essentially different from that of the lender: he has parted with property and demands a return." 32 Of course, by 37 Hen. VI (1459) any idea that the plaintiff vendor really owned the money due on a sale of a chattel has disappeared, and the conception has become merely a legal fiction. "As if I say to a man that if he is willing to carry 20

${ }^{20}$ Ames's "Parol Contracts Prior to Assumpsit," viii Harvard Law Review, at page 260 (I894).

"1 Pollock and Maitland's History of English Law, vol. ii, page 208.

"See note 3I. supra. 
quarts of wine of my master Prisot to $G$, he shall have 40 shillings. Now in this matter, if he carries the 20 quarters he shall have a good action of debt against me for the 40 shillings, and still the thing is not done to me but my commandment." 33

In the second place the gist of debt was never a promise, but originally the receipt of tangible property, and later the performance of some act at the request of the debtor, which gave rise to the obligation.

The development of this conception is easily traced in the Year Books. "It enters no one's head that a promise is the ground of this action. No pleader propounding such an action will think of beginning his count with 'Whereas the defendant promised to pay;' he will begin with 'Whereas the plaintiff lent or (as the case may be) sold or leased to the defendant.' In short, he will mention some causa debendi and that cause will not be a promise." 34

In order to constitute a debt it was of course necessary in the earliest times that what we call a "real contract" should exist. Debt was an action that could only be brought on a real contract. $^{35}$

"If there was a contract to pay money, the only question was how you could prove it. Any such contract which could be proved by any of the means known to early law constituted a debt. There was no theory of consideration, and therefore, of course, no limit to either the action or the contract based upon the nature of the consideration received." 36

But subsequently the conception of debt developed, and with it the right of action of the beneficiary. It became no longer essential that the quid pro quo should be an actual receipt of a tangible thing by the defendant. It is altogether erroneous to imagine that mediæval law required the quid pro quo, which gave rise

${ }^{23}$ Year Book, 37 Hen. VI, pl. I8, page 8.

* Pollock and Maitland's History of English Law, vol. ii, page 208.

${ }^{25}$ Ames, Parol Contracts Prior to Assumpsit, viii Harvard Law Review, passin.

${ }^{30}$ Holmes on the Common Law, pages $269-271$. 
to the obligation of debt, to be given to the promisor or debtor at the time he made his promise. On the contrary, as early as I4II, I2 Henry IV, it appears to be acknowledged law that "if money is promised to a man for making a release, and he makes the release, he shall have action of debt on the matter" (or transaction). ${ }^{37}$ A debt in 37 Henry VI would arise where a service was performed by the plaintiff at the request of the defendant, although the service was performed after the promise was made.

In debt, until 37 Hen. VI (1459), the quid pro quo had to be actually received by the defendant before he could be charged as a debtor. But as the law developed, although debt was based originally on the delivery of property to the defendant, the quid pro quo might consist, in I2 Hen. IV, as we have above seen, in the execution of an instrument on request and finally, in 37 Hen. VI ( 1459 ), in a service rendered to some third person at the request of the defendant. This development of debt from $9 \mathrm{Hen}$. $V$ ( I422), where a benefit conferred on a third person at the defendant's request was held not to give rise to debt, to the 37 Hen. VI (I459), when such a benefit so conferred was by familiar law a quid pro quo, has been clearly traced by Ames. ${ }^{38}$

The above cited case from the Year Book of 37 Hen. VI shows by two illustrations the expansion of debt from a "real contract" into an obligation arising upon a requested performance.

Not only does the case of the wine above cited as familiar law show this development, but in the same case Moyle, J., puts

"Year Book, I2 Henry IV, folio I7, pl. 13, at end of case.

ss "Originally there was no quid pro quo to create a debt against a defendant if the benefit was conferred upon a third person, although at the defendant's request."

"It became a settled rule that whatever would constitute a quid pro quo, if rendered to the defendant himself, would be none the less a quid pro quo, though furnished to a third person, provided that it was furnished at the defendant's request, and that the third person incurred no liability therefor to the plaintiff."

"But it is an indispensable condition of the defendant's liability in debt in cases where another person received the actual benefit, that this other person should not himself be liable to the plaintiff for the benefit received."-JAMES BARR Axes, "Parol Contracts Prior to Assumpsit," viii Harvard Law Review, pages $262-263$. 
this further illustration of the expanded doctrine of debt: "As if I should say to a surgeon that if he will go to J, who is sick, and cure him, he shall have roos. Now if he cures him he shall have a good action of debt against me for the roos, and still the thing is done to another and nothing to the defendant himself, and so he has no quid pro quo but the same in effect." 39

The important relation of this development of debt to the present inquiry as to the right of action of the beneficiary is unquestionable; though, so far as I am aware, not heretofore noted in this connection.

When debt expanded into an obligation based upon a performance requested by the debtor, the quid pro quo was, of course, required to be performed before the action of debt could arise. This was the distinction which marked the line between the action of debt and the action on the case on a consensual contract.

Hence, if $B$, in consideration of A's promise, promises to $A$, immediately or before $A$ 's performance, to pay to $C \mathfrak{E}$ Io, $C$ could have no action of debt because there was no contract between $A$ and $B$, based upon a requested performance, and the remedy must be action on the case.

But in debt, as above pointed out, the action would lie where the quid pro quo was received subsequent to the promise. We have previously seen that the receipt of a quid pro quo would give rise to an action in favor of the beneficiary. The principle that the quid pro quo might be rendered subsequent to the promise would necessarily apply to a promise in favor of a third party, though no cases to that effect have been found. On principle, therefore, the formula may be thus stated :

If $A$, at $B$ 's request, performs some service, when the requested service is performed $B$ 's promise to pay $A$ if performance should be rendered gives rise to an action of debt by $A$ v. $B$.

If, therefore, the promise made by $\mathrm{B}$ to $\mathrm{A}$ for a future quid pro quo was not to pay A but to pay $C$, there is no legal objec- 
tion to C's recovery against $B$. This, of course, is subject to the general limitation that the service shall not consist of a benefit rendered a third party who "shall himself be liable to the plaintiff for the benefit received."

Undoubtedly it always remained a settled rule of law, that in debt the action could only lie where the defendant had received something more than a mere promise. A later age, the legal phraseology of which, as applied in assumpsit, has invaded all our conceptions of contractual liability, will speak of an "executed consideration;" but in debt, from the earliest to the latest times, there was no consideration, and hence it tends only to confusion of thought to say that "the consideration" must be "executed" and not "executory." To us this expression perhaps better conveys the conception of the mediæval lawyer, who was well aware that in debt there must be the actual receipt of a piece of property or a benefit actually conferred before there could exist what he called a "contract" 40 on which to found debt, but the promise and the quid pro quo did not require to exist simultaneously, and the quid pro quo might be rendered to a third party. The plaintiff in debt was not required to be the promisee nor was he required to have furnished the quid pro quo.

* See Ames's Definitions in viii Harvard Law Review, page 253, note 3.

Craweford D. Hening.

(To be continued.) 